\title{
Reversible histoarchitecture study of testis and cauda epididymis and changes in cauda epididymal epithelial cell types on treatment with benzene extract of Ocimum sanctum leaves in albino rats
}

\author{
Mukhtar Ahmed $^{1,2}$, R Nazeer Ahamed ${ }^{1}$, RH Aladakatti ${ }^{1,3, *}$ and Deepthi $\mathrm{KR}^{3}$ \\ ${ }^{I}$ Department of Post-Graduate Studies and Research in Zoology, Karnatak University, Dharwad-580003, India; \\ ${ }^{2}$ Institute of Bioinformatics, Discoverer Building, 7th Floor, International Tech. Park, Bangalore-560066, India; \\ ${ }^{3}$ Central Animal Facility, Indian Institute of Science, Bangalore-560012, India
}

Received for publication February 26, 2007; accepted October 10, 2007

\begin{abstract}
SUMMARY
In the present study, an attempt has been made to assess whether the effect of benzene extract of Ocimum sanctum leaves on the ultrastructural changes in the epithelial cells of the cauda epididymis, its subsequent recovery in the seminiferous epithelium and fertility of male albino rats. Wistar strain male albino rats were orally administered benzene extract of $250 \mathrm{mg} / \mathrm{kg}$ body weight of $O$. sanctum leaves followed by subsequent recovery maintaining suitable controls for 48 days. Results indicate decrease in the weights of testis, epididymis and seminal vesicles. Other accessory organs were not affected. Total count, cell and nuclei diameters of germ cells and Leydig cells were reduced. Cauda epididymis exhibited significant reduction in epithelial height and nuclei diameter of epithelial cells. Cells showed vacuolization with exhibit of signs of degeneration. Ultra study revealed that, in general, the cauda epididymis was affected and in particular, the principal, clear and basal cells were highly disturbed. Further, there was decrease in the size of lipid droplets, mitochondria, Golgi complex, endoplasmic reticulum and accumulation of lysosomal bodies. Fertility performance test showed no implantation in female rats mated with $O$. sanctum treated rats. Moreover, their recovery after withdrawal of treatment was observed suggesting that the effect of the treatment is transient and reversible. A recovery period resulted in normal spermatogenesis and fertility, suggesting reversible antispermatogenic and antifertility effects of the plant.
\end{abstract}

Key words: Ocimum sanctum; Testis; Germ cells; Cauda epididymis; Epithelial cells; Albino rats

\section{INTRODUCTION}

Ocimum sanctum Linn. (Laiatae family) commonly called tulsi has been recognized for its unique properties. It is an important medicinal plant, held sacred by Hindus all over India and frequently

\footnotetext{
*Correspondence: RH Aladakatti, Central Animal Facility, Indian Institute of Science, Bangalore-560012, India. Email: renath_katti@yahoo.com
}

grown in gardens, courtyards and temples. It is used as antibacterial, insecticidal, diaphoretic in malarial fever, antiperiodic in gastric and genitourinary systems (Kirtikar and Basu, 1935; Nadkarni, 1954). Additionally, the leaves of $O$. sanctum; a) significantly altered the weight of testis, reducing the sperm count and motility (Seth et al., 1981); b) cause a decrease in $\mathrm{pH}$, hypertonic environment and differences in concentration of chemical substances 
of biological importance i.e. mucoprotein, alkaline phosphatase and acid phosphates (Kashinathan et al., 1971); c) reduce the mating behaviour of both male and female albino rats (Khanna et al., 1986; Kantak and Gogate, 1992; Sardessai et al., 1999); and d) significantly altered the sperm count, motility, velocity and fructose contained in the cauda epididymis of male albino rats (Mukhtar Ahmed et al., 2002). Hence, the present study was aimed to elucidate the effect of benzene extract of $O$. sanctum leaves on the ultrastructural changes in the epithelial cells of the cauda epididymis, its subsequent recovery in the seminiferous epithelium and fertility of male albino rats.

\section{MATERIALS AND METHODS}

\section{Preparation of test material}

Fresh $O$. sanctum leaves were collected and dried in shade. A voucher specimen (Zoo/herb/File No.47Acc.No.22) was deposited at Zoology Department, Karnatak University, Dharwad, India. The dried leaves were coarsely powdered and subjected to soxheltation process to get the benzene extract. Benzene was separated and extract thus obtained was allowed to dry and stored in a desiccator at $4^{\circ} \mathrm{C}(\mathrm{WHO}, 1983)$. Here it is called benzene extract. The benzene extract was then mixed with propylene glycol as required and administered orally (by gavage) to the experimental animals.

\section{Animals}

Adult male albino rats of Wistar strain, 3 months old and 190 to $200 \mathrm{~g}$ body weights were acclimatized to laboratory conditions and received a standard rat pellet diet (Gold Mohar, Hindustan Level Ltd., Hyderabad) and water ad libitum. The rats were divided into four groups comprising ten animals each.

\section{Study protocol}

The animals of group I, which served as control, were administered $1 \mathrm{ml}$ propylene glycol/rat/day orally for 48 days and autopsied $24 \mathrm{~h}$ later, the animals of group II, III and IV were administered $250 \mathrm{mg} / \mathrm{kg}$ body weight of benzene extract of $O$. sanctum leaves in $1 \mathrm{ml}$ of propylene glycol/rat/ day orally for 48 days. The animals of group II were autopsied on day $49^{\text {th }}$ and those of III and IV on day $8^{\text {th }}$ and $16^{\text {th }}$ after withdrawal of treatment, respectively. The effective dose of $250 \mathrm{mg} / \mathrm{kg}$ body weight has been arrived at after preliminary studies (Kashinathan et al., 1971; Seth et al., 1981; Mukhtar Ahmed, 1999) on dose and duration of 48 days is concerned to the spermatogenic cycle of rat in response studies in our laboratory and reported else where (Mukhtar Ahmed et al., 2002).

Five animals from each group were used for fertility test. Twenty-four hours after the last dose, the control and treated animals were sacrificed by cervical dislocation. The testis, epididymis, vas deference, seminal vesicle, ventral prostate, Cowper's, coagulatory and ampullary glands were dissected out, blotted free of mucus and weighed to the nearest milligram. For histological study, the testes and cauda epididymidis were fixed in aqueous Bowin's fluid for $24 \mathrm{~h}$, washed thoroughly in $70 \%$ alcohol, cleared in benzene and embedded in paraffin wax. Sections of $5 \mu \mathrm{m}$ thickness were obtained and stained in haematoxylin (Delafield's) and eosin. For histometrical studies, the calibrated ocular micrometer (Erma, Japan) was used. From each testis and epididymis, $20 \mathrm{~s}$ randomly were used in each group to record the histometrical data.

\section{Ultrastudy of cauda epididymis:}

The epididymis was removed, rapidly fixed in 3\% glutaraldehyde in phosphate buffer ( $\mathrm{pH} 7.4 ; 0.1 \mathrm{M}$ ) for $4 \mathrm{~h}$ at $4^{\circ} \mathrm{C}$, washed in phosphate buffer and post-fixed in $1 \%$ osmium tetraoxide in phosphate buffer ( $\mathrm{pH} 7.4 ; 0.1 \mathrm{M})$ for $6 \mathrm{hr}$. The fixed epididymis was washed several times in distilled water, stained en bloc in $2 \%$ aqueous uranyl acetate for $6 \mathrm{~h}$, dehydrated in acetone series, infiltered in eponaraldite mixture for $10 \mathrm{~h}$ and embedded in the same media in a beam capsule. The blocks were cut 
in LKB Broma ultramicrotome. Semithin sections of $1 \mu \mathrm{m}$ thickness were stained with toludine blue for identification of stages. Ultrathin sections were cut at $100-300 \mathrm{~A}^{\circ}$, mounted on copper grids and stained with $1 \%$ aqueous uranyl acetate and lead citrate (Reynolds, 1963). The stained sections were scanned in Jeol-TEM 100 C X II electron microscope for ultrastructural observations.

\section{Fertility test}

To assess the fertility rate with reference to the number of implantations, the female rats of proven fertility exhibiting regular estrous cycles and those in early proestrus or estrous stage were separately housed with the males of groups, I, II, III and IV and left overnight. The appearance of sperm in the vaginal smear next morning confirmed the mating and is considered as day 1 of the pregnancy. After 8 days, the females were laparotomized and the numbers of implantations were recorded. Number of pups and their weights on day 1 and after 1 week were recorded.

\section{Statistical analysis}

The data were presented as mean \pm S.E.M. The comparison of data for statistically significant differences was done using students ' $\mathrm{t}$ ' test and a probability level of $P<0.01$ and $P<0.001$ were considered as significant and highly significant, respectively.

\section{RESULTS}

\section{Body and organ weights (Table 1)}

The body weight of the rats did not differ significantly due to the treatment of benzene extract of $O$. sanctum leaves. However, there was slight but insignificant $(P<0.05)$ increase in the body weight two weeks after withdrawal of the treatment. Whereas, the weights of testis, epididymis and seminal vesicle decreased significantly in the treated $(P<0.001)$ rats as compared to the control. However, the weights of other accessory structures namely vas deference, ventral prostate, Cowper's, coagulatory and ampullary glands remained unchanged. One week after withdrawal of the treatment, the weight of testis, epididymis and seminal vesicle regained to the normal value. All the parameters were similar to controls two weeks after cessation of the treatment (Table 1).

\section{Histology}

Testis

The testis of control rats exhibited different stages in seminiferous elements comprising of germ cells, Sertoli cells and interstitial cells which are normal

Table 1. Effect of treatment of $O$. sanctum leaves on the body weight $(\mathrm{g})$, testis and accessory organs weight (mg/ $100 \mathrm{~g}$ body weight) and their recovery after withdrawal of treatment in albino rats (values are expressed in S.E.M. of five animals)

\begin{tabular}{|c|c|c|c|c|c|c|c|c|c|}
\hline Group & $\begin{array}{c}\text { Body } \\
\text { weight }\end{array}$ & Testis & $\begin{array}{l}\text { Epididy- } \\
\text { mis }\end{array}$ & $\begin{array}{l}\text { Vas defer- } \\
\text { ens }\end{array}$ & $\begin{array}{c}\text { Seminal } \\
\text { vesicle }\end{array}$ & $\begin{array}{l}\text { Ventral } \\
\text { prostate }\end{array}$ & $\begin{array}{c}\text { Cowper's } \\
\text { gland }\end{array}$ & $\begin{array}{l}\text { Coagula- } \\
\text { tory gland } 1\end{array}$ & $\begin{array}{l}\text { Ampul- } \\
\text { lary gland }\end{array}$ \\
\hline I & 195.20 & 571.20 & 261.60 & 53.90 & 163.20 & 94.70 & 27.60 & 21.30 & 17.10 \\
\hline Control & \pm 0.80 & \pm 2.25 & \pm 1.06 & \pm 2.36 & \pm 0.75 & \pm 3.24 & \pm 1.56 & \pm 2.69 & \pm 0.99 \\
\hline II & 197.60 & 553.80 & 249.50 & 52.40 & 158.30 & 90.90 & 26.30 & 19.40 & 17.00 \\
\hline O.Sanctum & \pm 1.12 & $\pm 2.55^{\text {*** }}$ & $\pm 1.62^{* * *}$ & \pm 3.81 & $\pm 1.10^{* *}$ & \pm 6.74 & \pm 5.30 & \pm 3.38 & \pm 3.08 \\
\hline $\begin{array}{c}\text { III } \\
\text { One week } \\
\text { recovery }\end{array}$ & $\begin{array}{l}197.20 \\
\pm 0.97\end{array}$ & $\begin{array}{l}566.30 \\
\pm 1.16\end{array}$ & $\begin{array}{l}259.20 \\
\pm 1.51\end{array}$ & $\begin{array}{l}52.93 \\
\pm 3.18\end{array}$ & $\begin{array}{l}162.57 \\
\pm 1.10\end{array}$ & $\begin{array}{r}93.92 \\
\pm 1.17\end{array}$ & $\begin{array}{r}28.96 \\
\pm 3.38\end{array}$ & $\begin{array}{r}18.47 \\
\pm 2.77\end{array}$ & $\begin{array}{r}17.42 \\
\pm 3.92\end{array}$ \\
\hline $\begin{array}{c}\text { IV } \\
\text { Two week } \\
\text { recovery }\end{array}$ & $\begin{array}{l}198.80 \\
\pm 0.73^{*}\end{array}$ & $\begin{array}{l}569.43 \\
\pm 1.55\end{array}$ & $\begin{array}{l}259.85 \\
\pm 2.51\end{array}$ & $\begin{array}{l}54.59 \\
\pm 2.82\end{array}$ & $\begin{array}{l}163.96 \\
\pm 1.05\end{array}$ & $\begin{array}{r}94.65 \\
\pm 3.82\end{array}$ & $\begin{array}{c}28.74 \\
\pm 3.76\end{array}$ & $\begin{array}{l}20.16 \\
\pm 2.60\end{array}$ & $\begin{array}{c}18.11 \\
\pm 1.49\end{array}$ \\
\hline
\end{tabular}




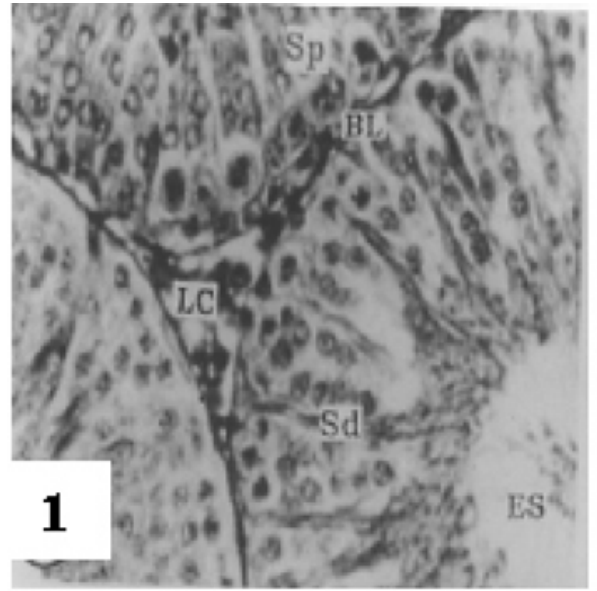

Fig. 1. Section of the seminiferous tubules of the control rat $\times 400$.

in their appearance. Towards the lumen, the primary spermatocytes, secondary spermatocytes, early spermatids and late spermatids were associated with Sertoli cells. Spermatogenesis was advanced to Golgi phase spermatids and some showed cap phase spermatids. Towards the lumen, arrangement of mature spermatozoa and formation of residual bodies could be observed under higher magnification (Fig. 1). Morphometric data is presented in Tables 2-4.

The rats treated with $O$. sanctum leaves showed atrophic tubules and spermatogenesis was very much suppressed, arrested in majority of the tubules. The tunica propria was disintegrated. Basement membrane was thin and disrupted. Spermatogenesis was arrested either at the primary spermatocytes or the spermatogonial stages. In some tubules, complete cytolysis of the entire spermatogenic elements was seen. The Sertoli cells showed vacuolization and cell debris due to cytolysis. The spermatogenesis did not advance beyond pachytene

Table 2. Effect of treatment of $O$. sanctum leaves on total count of seminiferous tubules, germ cells, Leydig cells and Sertoli cells and their recovery after withdrawal of treatment in the testis of albino rats (values are expressed in S.E.M. of five animals)

\begin{tabular}{ccccccc}
\hline & \multicolumn{5}{c}{ Number of } \\
\cline { 2 - 6 } Group & $\begin{array}{c}\text { Seminiferous } \\
\text { tubules in micro- } \\
\text { scopic field }(10 \times)\end{array}$ & Spermatogonia & Spermatocytes & Spermatids & Leydig cells & Sertoli cells \\
\hline I Control & $17.70 \pm 0.26$ & $116.90 \pm 2.49$ & $557.65 \pm 38.41$ & $967.45 \pm 8.39$ & $37.50 \pm 0.79$ & $22.70 \pm 0.68$ \\
\hline II O. sanctum & $22.25 \pm 0.56^{* * *}$ & $91.05 \pm 1.64^{* * *}$ & $310.35 \pm 2.51^{* * *}$ & $759.95 \pm 3.51^{* * *}$ & $25.80 \pm 1.01^{* * *}$ & $15.35 \pm 0.70$ \\
\hline $\begin{array}{c}\text { III One week } \\
\text { recovery }\end{array}$ & $21.10 \pm 0.65$ & $101.70 \pm 1.56^{* * * *}$ & $436.35 \pm 0.82^{*}$ & $852.35 \pm 2.75^{* * * *}$ & $30.30 \pm 0.62^{* * * *}$ & $22.85 \pm 0.53$ \\
\hline $\begin{array}{c}\text { IV Two week } \\
\text { recovery }\end{array}$ & $19.20 \pm 0.47$ & $116.70 \pm 2.96$ & $554.60 \pm 5.57$ & $977.35 \pm 5.15$ & $36.45 \pm 0.80$ & $22.35 \pm 1.06$ \\
${ }^{*} P<0.05,^{* * *} P<0.001$. & & & & &
\end{tabular}

Table 3. Effect of treatment of $O$. sanctum leaves on diameter of seminiferous tubules, germ cells $(\mu \mathrm{m})$ and their recovery after withdrawal of the treatment in the testis of albino rats (values are expressed in S.E.M. of five animals)

\begin{tabular}{lcccc}
\hline \multirow{2}{*}{ Group } & \multicolumn{1}{c}{$10 \times$} & $100 \times$ & \\
\cline { 2 - 5 } & $\begin{array}{c}\text { Seminiferous tubules } \\
(\mu \mathrm{m})\end{array}$ & $\begin{array}{c}\text { Spermatogonia } \\
(\mu \mathrm{m})\end{array}$ & $\begin{array}{c}\text { Spermatocytes } \\
(\mu \mathrm{m})\end{array}$ & $\begin{array}{c}\text { Spermatids } \\
(\mu \mathrm{m})\end{array}$ \\
\hline I Control & $262.79 \pm 3.79$ & $11.20 \pm 0.21$ & $9.30 \pm 0.29$ & $9.15 \pm 0.29$ \\
II O. sanctum & $237.50 \pm 1.18^{* * *}$ & $5.95 \pm 0.18^{* * *}$ & $5.05 \pm 0.21^{* * *}$ & $4.90 \pm 0.19^{* * *}$ \\
III One week recovery & $254.20 \pm 7.37$ & $7.25 \pm 0.80^{* *}$ & $6.00 \pm 0.19^{* * *}$ & $6.45 \pm 0.49^{* * *}$ \\
IV Two week recovery & $261.32 \pm 3.89$ & $11.05 \pm 0.20$ & $9.75 \pm 0.28$ & $9.70 \pm 0.32$ \\
\hline
\end{tabular}

${ }^{* *} P<0.01,{ }^{* * * *} P<0.001$. 
Table 4. Effect of treatment of $O$. sanctum leaves on nuclear diameter $(\mu \mathrm{m})$ of the germ cells and their recovery after withdrawal of the treatment in the testis of albino rats (values are expressed in S.E.M. of five animals)

\begin{tabular}{lcccc}
\hline \multirow{2}{*}{ Group } & \multicolumn{4}{c}{$100 \times(\mu \mathrm{m})$} \\
\cline { 2 - 5 } & Spermatogonia & Spermatocytes & Spermatids & Leydig cells \\
\hline I Control & $10.40 \pm 0.21$ & $7.75 \pm 0.20$ & $7.05 \pm 0.09$ & $7.95 \pm 0.20$ \\
II O. sanctum & $5.75 \pm 0.20^{* * *}$ & $3.95 \pm 0.15^{* * *}$ & $4.00 \pm 0.19^{* * *}$ & $3.80 \pm 0.17^{* * *}$ \\
III One week recovery & $8.00 \pm 0.45^{* *}$ & $5.90 \pm 0.37^{* *}$ & $5.25 \pm 0.16^{* * *}$ & $5.27 \pm 0.53^{* *}$ \\
IV Two week recovery & $10.55 \pm 0.23$ & $8.35 \pm 0.24$ & $6.95 \pm 0.22$ & $8.05 \pm 0.18$ \\
\hline
\end{tabular}

${ }^{* *} P<0.01,{ }^{* * *} P<0.001$.

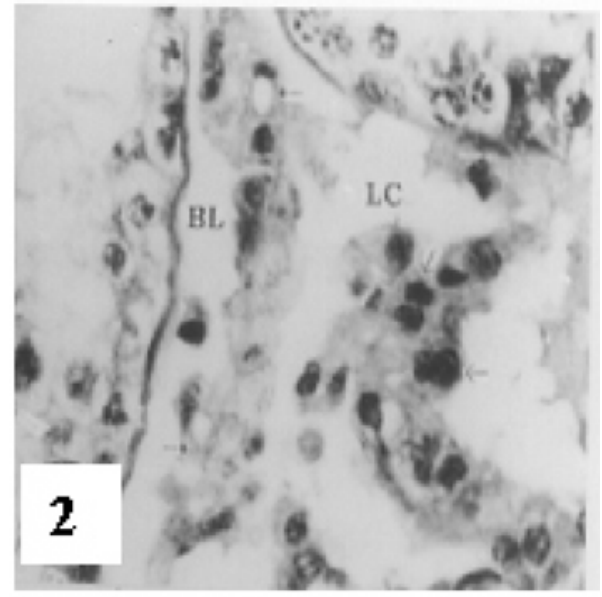

Fig. 2. Seminiferous tubules of the rat treated with $O$. sanctum leaves. Severe effects on the tubules and reduction in their size. Disruption of seminiferous epithelia is evident. Spermatogenesis stopped at the primary spermatocytes stage. Interstitial spaces increased and atrophy of Leydig cells, which are sparsely distributed. Giant cells are evident $(\leftarrow) \times 400$.

spermatocytes and few of these cells exhibited signs of degeneration and aggregate to form giant cells $(\leftarrow)$. The intercellular spacing becomes wider, Leydig cells were reduced in number or the interstitium contains mostly fibroblasts. Only occasional Leydig cells were discernible. There was preponderance of fibroblasts like elements over the Leydig cells with shrunken nuclei (Fig. 2).

The increase in the seminiferous tubules per microscopic field was highly significant (Table 2, $P$ $<0.001)$. The diameter of seminiferous tubules decreased significantly (Table $3, P<0.001$ ). There was highly significant decrease in the total count of spermatogonia, spermatocytes, spermatids, Leydig

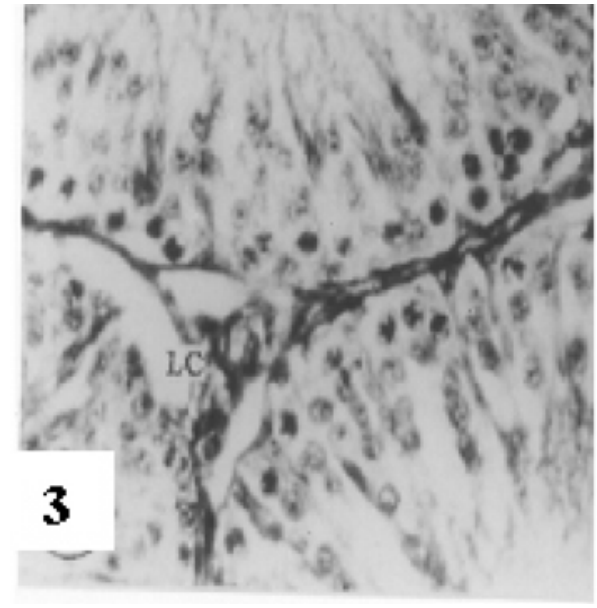

Fig. 3. Seminiferous tubules of one week of rats after one-week withdrawal. All the tubules are partially recovered $\times 400$.

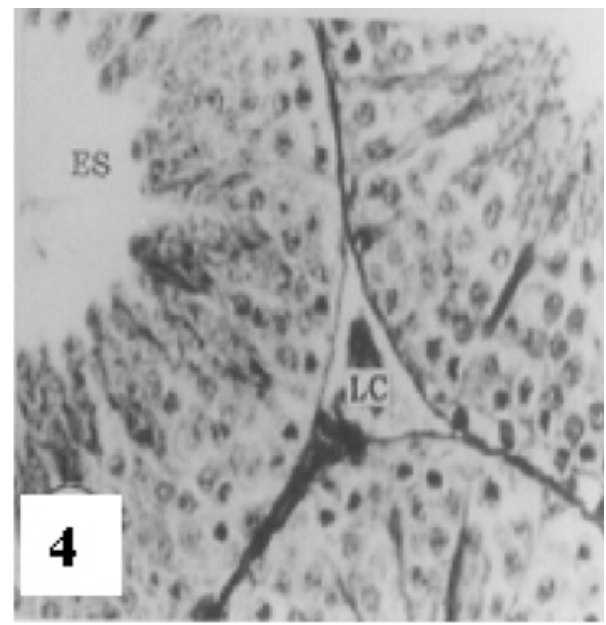

Fig. 4. Seminiferous tubules of two weeks of rats after withdrawal. A complete recovery is observed in all the stages of the spermatogenesis $\times 400$.

cells, and Sertoli cells (Table $2, P<0.001$ ). There was highly significant decrease in the cell and 
nuclear diameter of spermatogonia, spermatocytes, spermatids and the nuclear diameter of Leydig cells (Tables $3 \& 4, P<0.001$ ).

\section{Cauda epididymis}

The cauda epididymis of the control rats of the tubules arranged compactly with a very little intertubular connective tissue. The epithelium was low cuboidal and ciliated, along the luminal border. The cells contained prominent, spherical to oval nuclei and found very close to the basement membrane. The interstitium contained numerous interstitial cells with rounded nuclei and fibroblast like elements. The pseudostratified tubular epithelium consisting of very tall columnar principal cells with long, non-motile stereocillia and small basal cells.

Table 5. Effect of $O$. sanctum leaves (Benzene extract) on the epithelial height $(\mu \mathrm{m})$ and the nuclear diameter $(\mu \mathrm{m})$ of cauda epididymis of albino rats and its subsequent recovery (values are expressed as S.E.M. of five animals)

\begin{tabular}{lcc}
\hline \multirow{2}{*}{ Group } & \multicolumn{2}{c}{$100 \times(\mu \mathrm{m})$} \\
\cline { 2 - 3 } & $\begin{array}{c}\text { Epithelial height } \\
\text { (cauda) }\end{array}$ & $\begin{array}{c}\text { Nuclear } \\
\text { diameter (cauda) }\end{array}$ \\
\hline I Control & $23.35 \pm 0.39$ & $8.95 \pm 0.25$ \\
\hline II O. sanctum & $16.95 \pm 0.41$ & $4.90 \pm 0.26{ }^{* * *}$ \\
\hline $\begin{array}{l}\text { III One sweek } \\
\text { recovery }\end{array}$ & $19.95 \pm 0.60^{* * *}$ & $7.25 \pm 0.45^{*}$ \\
$\begin{array}{l}\text { IV Two week } \\
\text { recovery }\end{array}$ & $22.05 \pm 0.52$ & $8.50 \pm 0.28$ \\
\hline${ }^{*} P<0.05,{ }^{* *} P<0.01,{ }^{* * *} P<0.001$. &
\end{tabular}

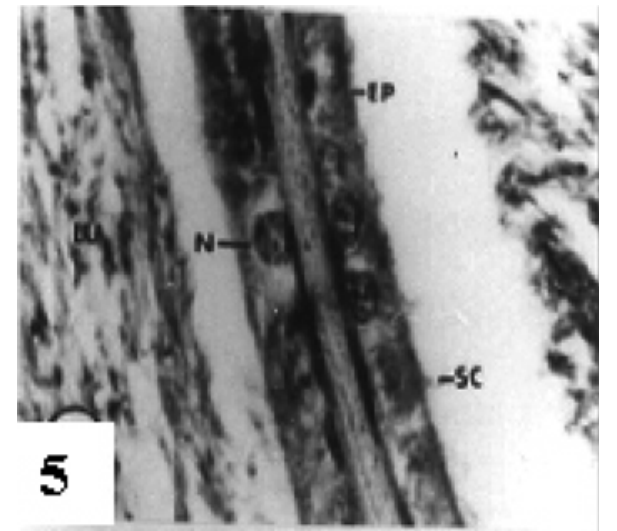

Fig. 5. In the cauda epididymis of the control rat, the epithelium (EP) exhibits the normal height and cells with intact nuclei $(\mathrm{N})$. The tubules are full of sperm with normal stereocillia (SC) $\times 100$. Lu: Lumen.

The stereo cilia were visible and the wide lumen packed with evenly dispersed sperm (Table 5, Fig. 5).

In the treated rats there was a reduction in the epithelial height and the nuclear diameter of the epithelial cells. The nuclei were pycnotic and the height of stereo cilia was reduced. The lumen was devoid of sperm and felled with lymphocytes and debris of degenerated sperm. Intertubular fibrosis was evident. The basement membrane was thin and disrupted. The cell showed vacuolization and the cell debris due to cytolysis. Few of these cells exhibited signs of degeneration (Figs. 6 - 8). There was a highly significant reduction $(P<0.001)$ in the epithelial height and nuclear diameter of the cauda
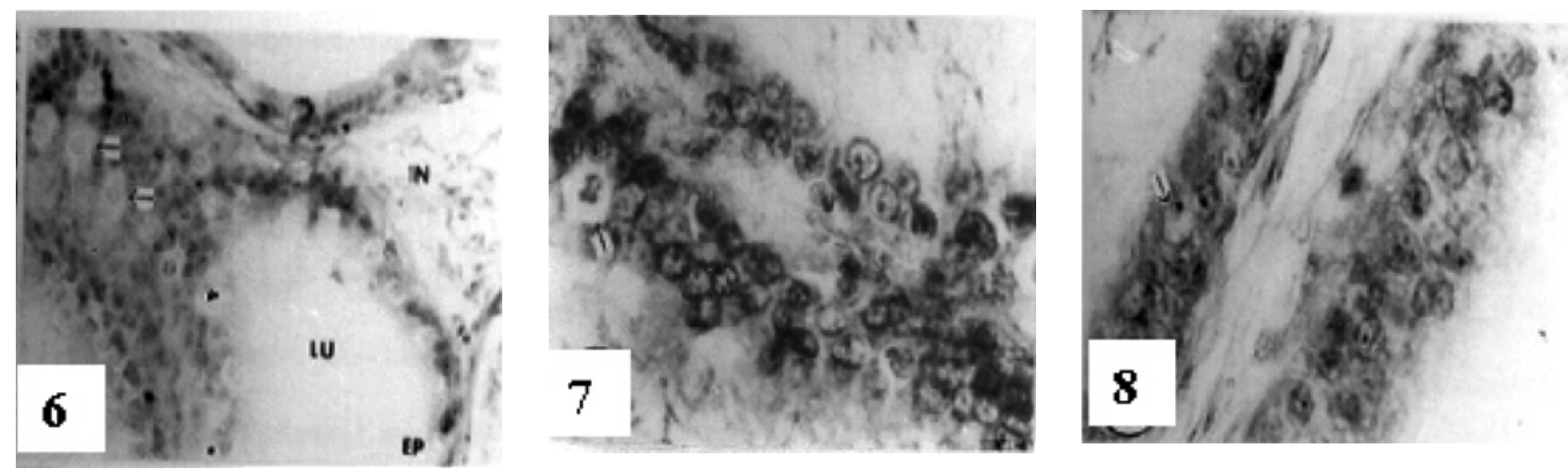

Figs. 6-8. In O.sanctum treated rats; the disrupted tubules show vacuolisation in the cells with condensed nuclei $(\leftarrow)$. The lumen $(\mathrm{Lu})$ is devoid of sperm with disruption interstitium (IN). The epithelium (EP) completely disturbed and reduced stereocillia (SC) $\times 100$. 
epididymis, when compared to controls (Table 5).

\section{One-week recovery group}

\section{Testis}

In the one-week recovery group a partial recovery was observed in the process of spermatogenesis. In some tubules the spermatogenic process was resumed with all the cellular stages and the lumen contained sperm. But in others the spermatogenic process was advanced only upto primary or secondary spermatocytes stage. Each seminiferous tubule revealed a typical adult organization of the spermatogenic cells and Sertoli cells with the tubular wall and the outermost basement membrane. In between the spermatogonial cells, the Sertoli cells were found (Fig. 3). The number of seminiferous tubules per microscopic field and diameter of the tubules were unchanged. The total count of the spermatogonia, spermatocytes, spermatids and Leydig cells were less, whereas, the Sertoli cells were normal, when compared to control animals. The cell and nuclear diameter of the spermatogonia, spermatocytes, spermatids and Leydig cells were also slightly recovered (Tables $3 \& 4, P<0.05$ ), when compared to control rats (Fig. 3).

\section{Cauda epididymis}

A partial recovery was observed in the tubules with inter tubular connective tissues. In epithelium, the epithelial height and the nuclei diameter recovered partially. The lumen was wide and packed with sperm. The interstitial cells were normal. The intertubular fibrosis was reduced and the sperm appeared in the lumen (Fig. 9).

\section{Two-week recovery group \\ Testis}

A complete recovery was observed in the process of spermatogenesis two weeks after withdrawal of treatment. Almost all the tubules regained the normal spermatogenesis and the lumen was full of sperm. Histological examination of the testis revealed no particular effect on spermatogenesis or

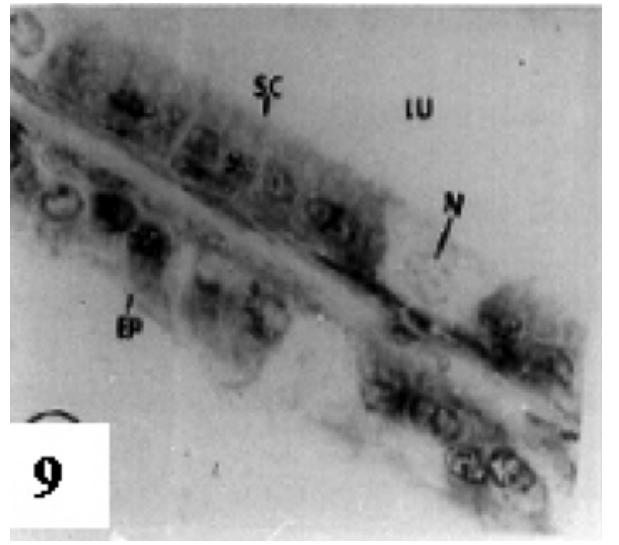

Fig. 9. Epithelium of the cauda epididymis of oneweek recovery group. A partial recovery is observed in the epithelium.

tubules. Leydig cells with rounded nuclei were observed in the interstitium. The spermatogenesis was advanced to pachytene spermatocytes, Golgi phase spermatids. Cap phase spermatids. Towards the lumen elongated spermatids were normal as in control. The spermatogenesis appeared qualitatively normal. Tubules contained many round spermatids with polarized nuclei, the majority of which were correctly aligned and few elongated spermatids and residual bodies were also apparent. Sertoli cells were normal. (Fig. 4, Tables 2 - 4).

\section{Cauda epididymis}

A complete recovery was observed in almost all the tubules. The epithelial height and nuclei diameter was fully recovered. The sperm were compactly arranged in the tubules. The interstitium was normal contained numerous interstitial cells with rounded nuclei and fibroblast like elements. The intertubular fibrosis was completely absent and the lumen was full of sperm. The stereocillia were also seen (Fig. 10).

\section{Ultrastructure of cauda epididymis}

In the control rats, the principal cells were present along the entire length of the cauda epididymis. These cells have a single round or elliptical nucleus containing granular chromatin. The multivesicular 


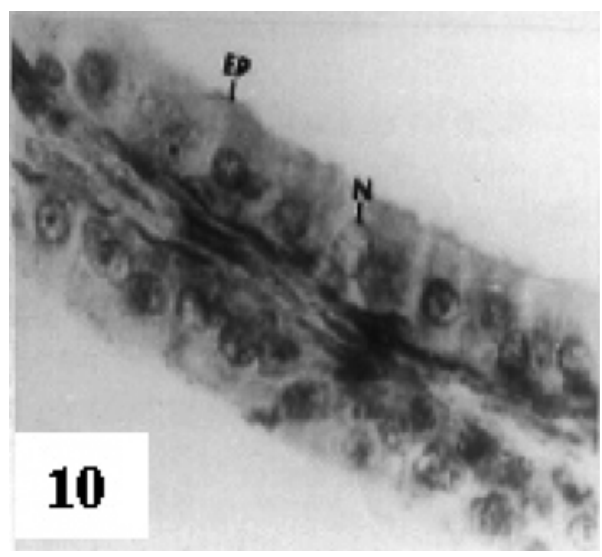

Fig. 10. Epithelium of the cauda epididymis of twoweek recovery group. complete recovery is observed in the epithelium, and the cell nuclei are intact.

bodies contain amorphous material. Golgi complex is composed of fenestrated cisternae. Supra nuclear region of the cell showed well developed mitochondrial cristae and endoplasmic reticulum arranged in the form of whorls (Fig. 11). The clear cells generally found in between the principal cells. They contained ovoid nuclei placed slightly above the basal position and contained granular chromatin material. The cytoplasm was abounded with lipid droplets. Micropinocytotic vesicles were prominent (Fig. 12). The basal cells were elliptical and nuclei were elongated and flattened against the basement membrane (Fig. 13).

The most obvious changes in the principal cell of cauda epididymidis of $O$. sanctum leaves treated rats were decreased in number of coated micropinocytotic vesicles, invaginations on the luminal surface, disruption of mitochondrial cristae and Golgi apparatus. The rough and smooth varieties of endoplasmic reticulum exhibit the changes in the structure. Further, the multivesicular bodies were increased and contained a homogenous or heterogenous material. The principal cell reflected the changes in terms of vesicular elements and lysosomal bodies. An interesting observation was that, the nucleus was highly indented and decreased in the size and the impact of the treatment was severe on the principal cells (Fig. 14). Micropinocytotic vesicles were rarely seen in the clear cells and a
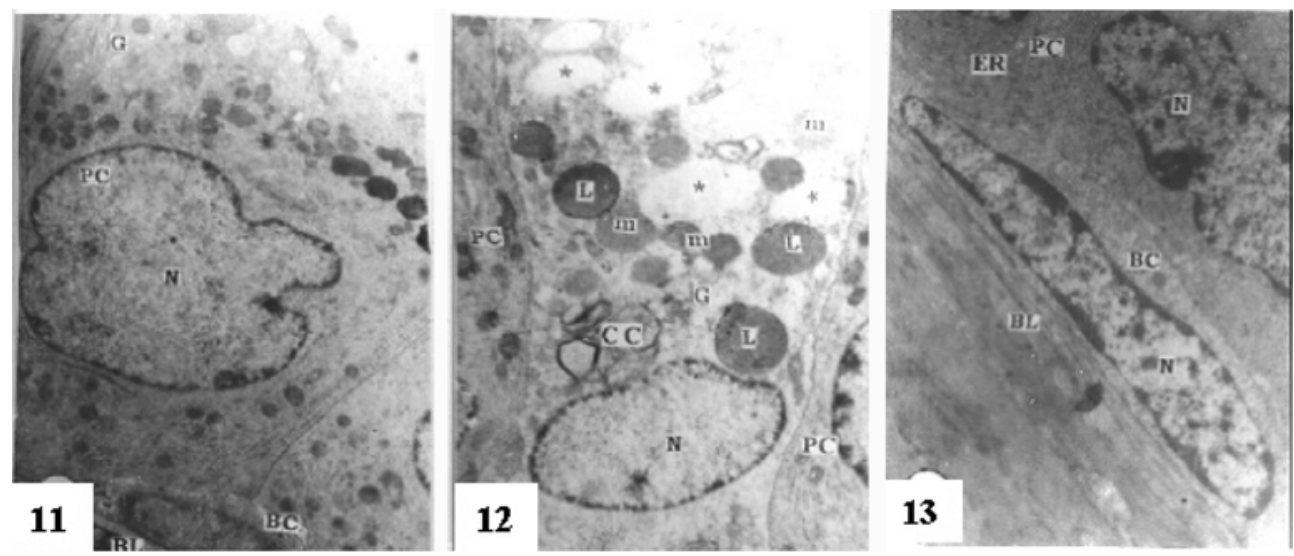

Fig. 11-13. Electron micrographs of control rat cauda epididymidis.

Fig. 11. Principal cell (PC) and Basal cell (BC) with normal Golgi complex (G). Supra nuclear region of the principal cells show features typical of the cell. Mitochondria are abundant and intact. The Nucleus (N) is normal. The demarcation between the cells is clear. The basal cell lies above the basal lamina (BL). Few lysosomal bodies are clearly visible $\times 2,000$.

Fig. 12. Clear cell (CC) is present showing its normal features between two principal cells (PC). The nucleus $(\mathrm{N})$ is normal lying at the basal lamina. Lysosomal $(\mathrm{L})$ and multivesicular bodies $(\mathrm{m})$ are also present. Endocytotic vesicles $(*)$ are also normal $\times 4,000$. G: Golgi apparatus.

Fig. 13. The basal cell (BC) is long showing normal in structure. The cell boundary is clearly seen. The nucleus (N) of the basal cell is lies parallel to the basal lamina (BL). Endoplasmic reticulum is visible and appears normal. The principal cell $(\mathrm{PC})$ adjacent to basal cell $(\mathrm{BC})$ is normal $\times 8,300$. ER: Endoplasmic reticulum. 

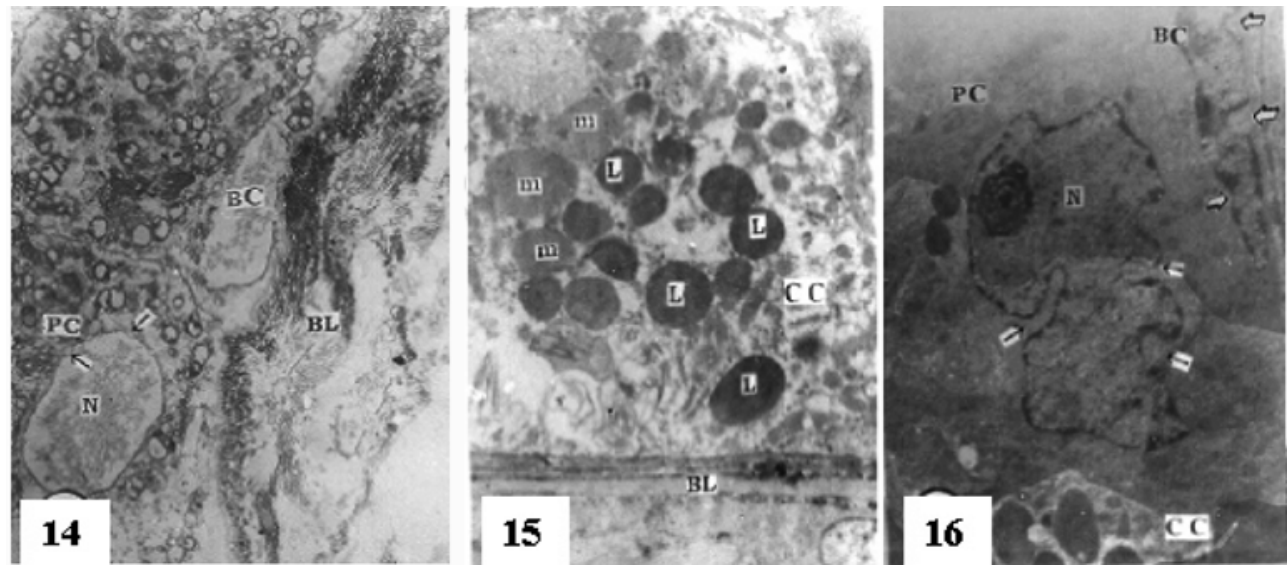

Fig. 14-16. Electron micrographs of Ocimum sanctum treated rat cauda epididymis.

Fig. 14. Principal cell (PC) and basal cell (BC) showing abnormal pattern. The nucleus (N) of principal cell with reduced chromatin material and there is bulging of nuclear envelope $(\leftarrow)$. The lysosomal bodies show complete degeneration and disruption mitochondrial cristae. The nucleus of basal cell (BC) show reduced nuclear chromatin material lying at the disrupted basal lamina $(\mathrm{BL}) \times 4,000$.

Fig. 15. Clear cell (CC) shows the absence of the nucleus in the plane of the section. The cell is totally disturbed and cell debris is seen prominently. The endocytotic vesicles are not visible. The multivesicular bodies (m) and lysosomal bodies (L) are increased $\times 5,200$. BL: Basal lamina.

Fig. 16. Cross-Section of principal cell (PC) and basal cell (BC). The principal cell nucleus $(\mathrm{N})$ is highly indented $(\leftarrow)$. The basal cell $(\mathrm{BC})$ is also showing the indentation (Hallow arrow) $\times 8,400$. CC: Clear cell

slight decrease in the number of multi vesicular bodies and mitochondria. The number of cytoplasmic vacuoles was reduced and the density of their flocculent content showed an increase. A cytoplasmic vacuoles and micropinocytotic vesicle were much reduced in the treated groups. A decrease was also evident in the size of lipid droplets in this cell. Autophagic bodies, containing remnants of cellular organelles, become particularly prominent in the perinuclear region of the cells indicating an enhancement of autophagic process within the cell. The multivesicular bodies were increased and contained heterogenous material in the supranuclear cytoplasm of cell. Lysosomal bodies increased either in the basal cytoplasm or the supranuclear cytoplasm or both. Further, in the plain of the section, the clear cells could be seen without a nucleus (Fig. 15). The basal cells showed the absence of the scattered spherical electron dense granules in the cytoplasm, disruption of mitochondrial cristae and Golgi apparatus. The varieties of rough and smooth endoplasmic reticulum were decreased in number and were disturbed. In the plain of the section, the nucleus became much indented with scattered chromatin material (Fig. 16).

\section{Fertility test}

Results of fertility performance test showed no implantation in female rats hen mated with $O$. sanctum treated male rats. However, the number of implantations, pups and their weights were restored to the control level in the female rats mated with one and two week recovery groups respectively (Table 6).

\section{DISCUSSION}

In conclusion, it has been reported that androgen is essential for most of the stages of the spermatogenesis, particularly for meiosis (Brooks, 1981). In the present study, the regression, degenerative changes in the seminiferous tubules, significantly decreased 
Table 6. Effect of treatment of $O$. sanctum leaves on the implantations, number of pups and their body weight of female rats mated with treated and recovered male rats (values are expressed in S.E.M. of five animals)

\begin{tabular}{lcccc}
\hline \multirow{2}{*}{ Group } & $\begin{array}{c}\text { No. of } \\
\text { implantations }\end{array}$ & No. of pups & \multicolumn{2}{c}{ Body weight of pups } \\
\cline { 4 - 5 } I Control & $10.20 \pm 1.07$ & $9.60 \pm 1.08$ & One day $(\mathrm{g})$ & One week $(\mathrm{g})$ \\
II O. sanctum & - & - & - & $8.60 \pm 0.07$ \\
III One week recovery & $8.20 \pm 0.73$ & $7.60 \pm 0.68$ & $5.81 \pm 0.13$ & $8.73 \pm 0.08$ \\
IV Two week recovery & $8.80 \pm 1.16$ & $8.80 \pm 1.16$ & $5.75 \pm 0.11$ & $8.78 \pm 0.08$ \\
\hline
\end{tabular}

number of Leydig cells and their nuclear diameter reflect the depletion of androgen level. It is supported by decreased number of germinal cells i.e., spermatocytes and spermatids since these changes are completely androgen dependent (Dym et al., 1979). The observations related to the unique nature of the change in the seminiferous tubules are similar as in every plant assayed so far in male anti-fertility perspective. Viz., Carica papaya (Lohiya and Goyal, 1992); Euphorbia nerrifolia (Mali and Chaturvedi, 1994); Azadirachta indica (Kasturi et al., 1997); Momordica charantia (Naseem et al., 1998); Coculus pendulus (Verma and Lall, 1999); methanol stem extract of Sarcostemma acidum (Roxb) Voigt (Verma et al., 2002); stem extract of Tinospora cordifolia (Willd) (Gupta and Sharma, 2003); ethanol extract of Semecarpus anacardium (Sharma et al., 2003); and saponins isolated from Albizia lebbeck bark (Gupta et al., 2005).

The accessory system of male ducts and glands are morphologically and physiologically dependent upon the production of androgens (WilliamsAshman and Reddy, 1972). In the present study, there was a significant reduction in the weights of testis, epididymis and seminal vesicle and complete suppression of fertility at the employed dose of rats treated with benzene extract of $O$. sanctum leaves. Since, testis, epididymis and seminal vesicle are androgen dependent, the regressive changes due to the treatment of $O$. sanctum in the present study, suggest the dwindling of androgen status or provides on indirect evidence for the anti-androgenic action of the plant.

The epididymis is an important component of the male reproductive tract that is highly androgen dependent and plays a vital role in the male fertility. Androgenic hormones reach the epididymis via the blood stream and also the fluid that accompanies the spermatozoa from the testis (Vreeburg, 1975). The epididymis provides a suitable environment for morphological and biochemical changes in spermatozoa (OregebeinCrist, 1969). It performs both secretory and absorptive functions. Androgen deficiency causes a marked reduction in the tubular diameter, a general regression of epididymal epithelium, a rapid decline in the number of spermatozoa with in the cauda epididymis and changes in the composition of epididymal plasma (Brooks, 1981). The disorganised epithelium of cauda epididymis and cells showed vacuolization with exhibit of signs of degeneration due to the treatment of benzene extract of $O$. sanctum leaves, thereby suggesting the dwindling of androgen status or provides an indirect evidence for the antiandrogenic action of the plant extract. Our present observations were similar to studies of Azadirachta indica (Joshi et al., 1996; Kasturi et al., 1997); Hibiscus rosasinesis (Madhusudana et al., 1997); papaya seed (Chinoy et al., 1997) and Nicotine, a tobacco extract, (Ramesh et al., 2000).

The epididymis in general and the principal cell in particular, are androgen dependent and androgen withdrawal is known to cause extensive changes in the principal cell (Akbarsha and Averal, 1998; Hermo and Robaire, 2002). Thus, the changes in the principal cell of treated rats may reflect a manifestation of hypoandrogenic status; brought about by treatment of benzene extract of $O$. 
sanctum leaves. Microtubules constitute a principal component of the tissue matrix system of the epithelial cells. It is possible; therefore, that benzene extract of $O$. sanctum leaves may have caused pathological changes in the cauda epididymal epithelial principal cell.

In the present study, principal cell, clear cell and basal cells underwent ultrastructural changes following treatment. Among the significant changes observed in the principal cells were decrease in the number of micropinocytotic vesicles and reduction in the size of the mitochondria and Golgi apparatus. Asha Prakash et al. (1979) have suggested that absorptive function of the principal cell is impaired following administration of cyproterone acetate, an antiandrogen. Thus, the findings in the present study lead us to infer hypoandrogenic status caused due to treatment of benzene extract of $O$. sanctum leaves. The results of the present study further indicated that in response to benzene extract of $O$. sanctum leaves treatment; the clear cells undergo hypertrophy, hyperplasia and hyperactivity in an attempt to remove the cell debris reaching the ductus epididymal lumen from the testis in the form of residual bodies, Sertoli cell fragments and dead and deformed sperm. Similar observations have been made in the cauda epididymis of rats treated with vincristine (Akbarsha and Averal, 1996, 1999). In the clear cell of the $O$. sanctum treated rats, organelles viz., cytoplasmic vacuoles, electron dense secretory granules and mitochondria, exhibited a reduction in abundance. Also the lipid droplets in the cells of the treated rats were smaller as compared with those in control rats. Further, there was a reduction in the number of micropinocytotic vesicles and multivesicular bodies. These findings indicate that the endocytic function of the clear cells is affected following benzene extract of $O$. sanctum leaves treatment. The available cytological evidence does not support the contention that the basal cells are involved either in secretion or in absorption. This conclusion is drawn from the observations that the basal cells are numerically less, their location is far away from the lumen and they do not have complex cellular machinery for secretion or absorption (Dutt, 1999). But Veri et al. (1993) and Regadera et al. (1993) have proposed a hypothesis that the basal cells are involved in a scavenging role in a local immune defence mechanism in which antigenic products derived from sperm degeneration are phagocytosed. The role of basal cells seems to be imperfectly understood, although these cells are present in all mammalian epididymis studies (Dutt, 1999).

The above ultrastructural changes indicate that the principal and clear cells are affected, thus altering the composition of the epididymal fluid, which in turn would affect sperm maturation. This contention is supported by findings of studies of vincristine (Akbarsha and Averal, 1996, 1998, 1999; Akbarsha et al., 2000) and Azadirachta indica leaves (Ghodesawar et al., 2004). The fertility studies reveal that the male rats treated with benzene extract of $O$. sanctum leaves are unable to fertilize the female rats probably because the male gametes are affected thereby, establishing the antifertility property of the plant studied. However, in the present study, a complete recovery after sixteen days of cessation of the treatment indicates that the effects of the treatment are transient and reversible. Similar studies of Semecarpus anacardium (Sharma et al., 2003); ethanol extract of Citrullus colocynthis (Chaturvedi et al., 2003); crude extract of Azadirachta indica leaves (Joshi et al., 1996) and triptolide (Huynh et al., 2000) have been shown that a gradual recovery was observed after withdrawal of the treatment.

The antifertility activity exhibited by plant extract may due to the presence o more than one compound. The activity is sometimes reduced or left when the extract is fractioned and separated into individual components. In case of $O$. sanctum leaves, the benzene, ethanol and ether extracts showed different degree of antifertility activity. Various extracts of $O$. sanctum leaves arrest spermatogenesis and are likely to have an antiandrogenic activity. Among, the benzene extract of $O$. sanctum leaves exerts antiandrogenic 
and antifertility effects in rats and mice without adverse toxicity and that the effects may be directly rendered on the spermatozoa (Kashinathan et al., 1971; Seth et al., 1981; Mukhtar Ahmed et al., 2002). Our present study has shown that administration of benzene extract of $O$. sanctum leaves has a similar antifertility effect in albino rats. We conclude that the some of the active principles responsible for the antiandrogenic of $O$. sanctum are present in the benzene extract. However, further in depth studies are needed to isolate the active principle of $O$. sanctum leaves in order to clearly elucidate its mechanism of action. Therefore, in the present study, the disorganised epithelium of cauda epididymis and cells showed vacuolization with exhibit of signs of degeneration due to the treatment of the benzene extract of $O$. sanctum leaves thereby suggesting the dwindling of androgen status or provides an indirect evidence for the antiandrogenic action of the plant extract and also possess reversible antispermatogenic effect on testis, epididymis and fertility rate of adult male albino rats.

\section{ACKNOWLEDGMENTS}

This research was supported by Department of Zoology, Karnatak University, India and Union Grant Commission under SAP and COSIST program, New Delhi, India. We also acknowledge National Institute of Mental Health and Neurosciences (NIMHANS), Bangalore, India for their kind help in electron microphotograph.

\section{REFERENCES}

Akbarsha MA, Averal HI. (1996) Epididymis as a target organ for the toxic effect of vincristine: light microscopic changes in the epididymis epithelial cell types. Biomed. Lett. 54, 133-146.

Akbarsha MA, Averal HI. (1998) Male reproductive toxicity of vincristine: Ultrastructural changes in the epididymal principal cell. Biomed. Lett. 57, 159-169. Akbarsha MA, Averal HI. (1999) Epididymis) as a target for the toxic manifestation of vincristine: Ultrastructural changes in the clear cell. Biomed. Lett. 59, 149-169.

Akbarsha MA, Averal HI, Girija R, Anandhi S, Faridha Banu A. (2000) Male reproductive toxicity of vincristine: Ultrastructural changes in the epididymal epithelial apical cell. Biomed. Lett. 102, 85-93.

Asha Prakash M, Rajalakshmi, Prasad MPN. (1979) Ultrastructural changes in the principal and clear cells in the rat epididymis following the administration of cyproterone acetate. Indian J. Exp. Biol. 17, 11591165.

Brooks DE. (1981) Metabolic activity in the epididymis and its regulation by androgens. Physiol. Rev. 61, 515-518.

Chaturvedi M, Mali PC, Ansari AS. (2003) Induction of reversible antifertility with a crude ethanol extract of Citrullus colocynthis Schrad fruit in male rats. Pharmacol. 68, 38-48.

Chinoy NJ, Patel KG, Sunita Chawla. (1997) Reversible effects of aqueous extract of papaya seed on microenvironment and sperm metabolism of cauda epididymis of rat. J. Med. Aromat. Plant Sci. 19, 717723.

Dutt NH. (1999) Structure of mammalian epididymis. Comp. endocrinol. Reprod. pp 201-227.

Dym M, Madhwaraj HG, Lin YC, Chenes HE, Kotite NJ, Nayteh SN, French FS. (1979) Is FSH required for maintenance of spermatogenesis in adult rats. J. Reprod. Fertil. Suppl. 26, 175-181.

Gupta RS, Sharma A. (2003) Antifertility of Tinospora cordifolia (Wild) stem extract in male rats. Indian J. Exp. Biol. 41, 885-889.

Gupta RS, Chaudhary R, Yadav RK, Verma SK, Dobhal MP. (2005) Effect of Saponins of Albizia lebbeck (L.) Benth bark on the reproductive system of male albino rats. J. Ethnopharmacol. 96, 31-36.

Ghodesawar MG, Nazeer Ahamed R, Mukhtar Ahmed A W, Aladakatti R H. (2004) Ultrastructural changes in cauda epithelial cell types in Azadirachta indica leaf treated rats. Indian J. Exp. Biol. 42, 10911095.

Hermo L, Robaire B. (2002) In The Epididymism from the Molecules to Clinical Practice, edited by B. Robaire \& BT Hinton, Kluwar Academic/Plenum Publishers, New York, pp. 81. 
Huynh PN, Sinha Hikim AP, Christina W, Ksenija S, Yan HL, Andrew L, Vince A, Sima B, Vichai R, Ronald SS. (2000). Long term effects of triptolide on spermatogenesis, epididymal sperm function and fertility in male rats. J. Androl. 21, 689-699.

Joshi A R, Nazeer Ahamed R, Pathan KM, Manivannan B. (1996) Effect of Azadirachta indica leaves on testis and its recovery in albino rats. Indian J. Exp. Biol. 34, 1091-1094.

Kantak NM, Gogate MG. (1992) Effect of short term administration of Tulsi (Ocimum sanctum Linn.) on reproductive behaviour of adult male rats. Indian J. Physiol. Pharmacol. 36, 109-111.

Kashinathan S, Ramakrishna S, Basu SL. (1971) Antifertility effect of Ocimum sanctum Linn. Indian J. Exp. Biol. 10, 23-45.

Kasturi M, Nazeer Ahamed R, Pathan KM, Shaikh PD, Manivannan B. (1997) Effect of Azadirachta indica leaves on the seminal vesicle and ventral prostate in albino rats. Indian J. Phisiol. Pharmacol. 41, 234-240.

Kirtikar KR, Basu BD. (1935) Indian medicinal plants, Lalit Mohan Basu, Allahabad, pp. 351.

Khanna SK, Gupta SR, Grover JK (1986). Effect of long term feeding of Tulsi (Ocimum sanctum L.) on reproductive performance of adult albino rat. Indian J. Exp. Biol. 24, 302-304.

Lohiya NK, Goyal RB. (1992) Antifertility investigations on the crude chloroform extract of Carica papaya Linn seeds in albino male rats. Indian J. Exp. Biol. 30, 1051-1055.

Madhusudana Reddy C, Rama Krishna Murty D, Saraswati Patil B. (1997) Antispermatogenic and androgenic activities of various extracts of Hibiscus rosasinesis in albino mice. Indian J. Exp. Biol. 35, 11701174.

Mali PC, Chaturvedi M. (1994) Inhibition of spermatogenesis with the $50 \%$ EtoH-extract of Euphorbia nerrifolia Linn root in male rats. Nat. Symp. Reprod. Health Care: Fifth Ann. Meet of the Ind. Soc. For the study of Reprod. Fertil. Jaipur, Abs, 6-7.

Mukhtar Ahmed. (1999) Studies on the effect of Ocimum sanctum leaves on the morphological changes in rat sperms by scanning electron microscope. M.Phil Dissertation, Karnatak University, Dharwad, India. Mukhtar Ahmed, Nazeer Ahamed R, Aladakatti RH,
Ghodesawar MG. (2002) Reversible antifertility effect of benzene extract of Ocimum sanctum leaves on sperm parameters and fructose content in rats. J. Basic Clin. Physiol. Pharmacol. 13, 51-59.

Nadkarni AK. (1954) Nadkarni's Indian meterica medica. Vol. I, II, III ed. Popular Book Depot, Bombay, pp. 868.

Naseem MZ, Patil SR, Ravindra, Patil SB. (1998) Antispermatogenic and androgenic activities of Momordica charanchita (Karela) in albino rats. J. Ethnopharmacol. 61, 9-16.

Oregebein-Crist ML. (1969) Studies on the function of the epididymis. Biol. Reprod. 1, 155.

Ramesh L, Londonkar, Avadhoot Sonar, Srinivasreddy Patil, Saraswati Patil B. (2000) Nicotine delays puberty in male rat. Pharmaceutical Biol. 38, 291-297.

Reynolds ES. (1963) The use of lead citrate at high $\mathrm{pH}$ as an electron-opaque stain in electron microscopy. J. Cell Biol. 17, 208-212.

Regadera J, Cobo P, Paniagua R, Martizoz-Garua F, Placios J, Nistal M. (1993) Immunohistochemical and semiquantitative study of the apical mitochondriarich cells of the human prepubertal and adult epididymis. J. Anat. 183, 507-514.

Sardessai SR, Borker AS, Abraham ME. (1999) Effects of short term administration of Tulsi leaves on sexual behaviour in female rats. Indian J. Physiol. Pharmacol. 43, 398-400.

Seth SD, Johri N, Sundaram KR. (1981) Antispermatogenic effect of Ocimum sanctum. Indian J. Exp. Biol. 19, 975976.

Sharma A, Verma PK, Dixit VP. (2003) Effect of Semecarpus anacardium fruits on reproductive function of male albino rats. Asian J. Androl. 5, 121-124.

Veri JP, Hermo L, Robaire B. (1993) Immunocytochemical localization of the Yf subunit of glutathione Stransferase $\mathrm{P}$ shows regional variation in the staining of epithelial cells of the testis, efferent ducts and epididymis of the male rat. J. Androl. 14, 23-44.

Verma PK, Sharma A, Mathur A, Sharma P, Gupta RS, Joshi SC, Dixit P. (2002) Effect of Sarcostemma acidum stem extract on spermatogenesis in male albino rats. Asian J. Androl. 4, 43-47.

Verma V, Lall SB. (1999) Effect of leaf extract of Cocculus pendulus on the testicular enzymology of the Swiss albino mice. Indian J. Environ. Toxicol. 9, 20-23. 
Vreeburg TM. (1975) Distribution of testosterone and $5 \alpha$ dihydrotestosterone in rat epididymis and their concentrations in efferent duct. Endocrinology 67, 203-210.

WHO Protocol, LG-06. (1983) Extraction and fractionation for biological and phytochemical studies. A.P.J.F/
I.P, A, pp. 1001-1083.

Williams-Ashman HG, Reddy AH. (1972) Androgenic regulation of tissue growth and function. In Biochemical actions of hormones. G. Litwack (edn.) Vol. II, Academic Press, New York. 